Bangladesh J. Plant Taxon. 23(2): 189-194, 2016 (December)

(C) 2016 Bangladesh Association of Plant Taxonomists

\title{
A NEW SPECIES OF LAPORTEA GAUDICH. (URTICACEAE) FROM HIMALAYA, INDIA
}

\author{
Bachan LaL Bhellum ${ }^{1}$ AND BiKarma Singh ${ }^{2}$ \\ Department of Botany, Government College for Women, Parade, Jammu, J \& K State, India
}

Keywords: Conservation status; Endangered; Laportea stolonifera; New species; Taxonomy.

\begin{abstract}
A new herb species of Urticaceae, Laportea stolonifera B. L. Bhellum \& B. Singh, is described and illustrated from a restricted habitat of subtropical forest of Northwest Himalaya, India. The new taxon is vegetatively similar to Laportea ovalifolia (Schumach. \& Thonn.) Chew, an African endemic species and Laportea interrupta (L.) Chew but differs by phenotypic characters such as cordate leaves, unbranched inflorescence, stem hairs types, linear cystoliths with varying shapes, and presence of 2 to 3 stolons arising from basal node of stems. The similarity with the allied species is due to similar habitats occupancy, but isolated geographically from each other. Laportea stolonifera is assessed as Endangered, and the population data, ecological parameters and associated taxa are also presented. A key to the genus Laportea is prepared for India has been presented in the text.
\end{abstract}

\section{Introduction}

The nettle family, Urticaceae Juss. (1789: 400), comprised of 1465 species and 54 genera in the world (TPL, 2016), includes herbs, shrubs, small trees, and vines distributed primarily in tropical, subtropical and temperate belts (Mabberley, 2008). While studying the floristic composition of Jammu and Kashmir (India) in Northwestern Himalaya, and during recent plant collection trips to Jasrota forest, samples from three interesting populations of tribe Urticeae were collected which upon critical investigation revealed to be a new species of the genus Laportea Gaudich.

The genus Laportea comprise of 25 species (TPL, 2016), chiefly distributed in Africa and Madagascar with a few pantropic species (Chew, 1989). In India it is represented by 4 species: $L$. aestuans (L.) Chew; L. bulbifera (Siebold \& Zucc.) Wedd.; L. interrupta (L.) Chew and $L$. stolonifera B.L. Bhellum \& B. Singh, sp. nov. Most of the Laportea species are confined to Northeast India, Northwest Himalaya and South India. Laportea sp. collected during recent field survey in Northwest India is morphologically similar to L. ovalifolia (Schumach. \& Thonn.) Chew. After thorough scrutiny of the specimens, literature survey and geographic distribution, authors found that the unknown species is new to science. The species is named as Laportea stolonifera B.L. Bhellum \& B. Singh, and is quite different from the species described in published literatures (Ramaswamy and Razi, 1973; Fyson, 1974; Bennet, 1987; Chew, 1989; Sharma, 2010). The specimen have been taxonomically described, photographed and illustrated. Data on populations, ecological parameters and associated taxa are also presented. The holotype voucher specimen is deposited at Janaki Ammal Herbarium (RRLH) at CSIR-Indian Institute of Integrative Medicine, Jammu (India).

${ }^{1}$ Corresponding author. Email: blbhellum@gmail.com / drbikarma@iiim.ac.in

${ }^{2}$ CSIR-Indian Institute of Integrative Medicine, Canal Road, Jammu-Tawi, India. 


\section{Materials and Methods}

Critical morphological work out on the newly discovered specimen were done by comparison and assessment of voucher specimen of the new taxa with that of the allied holotypes, isotypes and specimens housed at the various herbaria, viz. ASSAM, CAL, BSD, BPL, CVH and RRLH. Herbarium acronyms followed were those of Thiers (2015). Specimens were also examined together with Google images from the Plant Illustration (http://www.plantillustrations.org), TROPICOS (http://www.tropicos.org), and Global Plants Initiative (http://gpi.myspecies.info). While describing the species, field data pertaining to habit, ecology, shape and size of floral elements, leaves, mild stinging hairs, fruits and seeds were incorporated from the field diary. Associated plants of this particular species were presented along with the photographs. Fresh flowering materials were examined under trinocular microscope at $10 \mathrm{X}$ and $40 \mathrm{X}$ for proper description and illustration.

Laportea stolonifera B.L. Bhellum \& B. Singh, sp. nov.

(Figs 1\&2).

Diagnosis: The new species, Laportea stolonifera, is highly similar to the African endemic, L. ovalifolia, and some characters related with L. interrupta, but differ from them by the presence of cordate leaves, unbranched inflorescence, three types of stem mild hairs, linear cystolith with varying shapes, and salient characters of 2 or 3 stolons arising from each basal node of stems.

Type: INDIA. North-West Himalaya: Jammu and Kashmir State, Jammu Province, Jasrota forest, shady places along the forest margin, altitude $294 \mathrm{~m}$ above sea level, $32^{\circ} 33^{\prime} 59.1^{\prime \prime} \mathrm{N}$

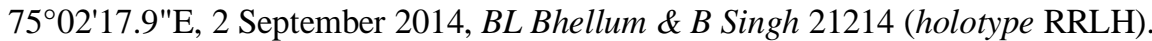

Annual herbs, $23-57 \mathrm{~cm}$ high; spreading along the ground by stolons and roots; rooting at the nodes, adventitious roots, thin, ca. $12 \mathrm{~cm}$ long. Stems woody at base, furrowed, half way glabrous, usually unbranched, greenish, clothed with three different types of mild stinging hairs, larger recurved beset with one, two or three stinging points, middle single with stinging hair spreading, base bulbous and shorter hair appressed, slightly curved. Petioles varies in size, depending on leaf blade size, 0.4-9.6 cm in length, presence of spreading stinging hairs; stipules interpetiolar, oblong, biclefted, segments linear, each segment prominently veined, hairy, sometimes exstipulate. Leaves simple, alternate, persistent, ovate-broadly ovate, varies in size, $1.0-8.4 \mathrm{~cm}$ long, 0.6-6.1 cm wide, matured ones cordate at base, young ones truncate at base, shortly acuminate at apex, membranous, upper surface packed with tiny sand-like cystoliths; margins crenate-dentate or coarsely serrated; stinging hairs on the upper surface short and shining, while those on the lower surface remotely hairy on lateral and basal nerves beneath; lateral nerves 5-6 pairs, prominent, basal nerves reaching more than half of the length of the blade; cystoliths linear, visible. Stolons arise from each node at the base of stem directly forming inflorescence, 2 or 3 in number. Inflorescence unisexual, arise from the nodes, racemes solitary, axillary spikes arranged in lax fascicles, 3-6 cm long, soon falling off after maturing; spikes armed with stinging hairs. Flower buds ellipsoidal, pale yellow or light green. Male flowers $1 \mathrm{~mm}$ long, tepals 4 or 5, subvalvate, depressed, usually inflexed in flower buds; stamens as many as tepals; rudimentary ovary clavate or subglobose; anthers bithecous, white, filaments inflexed in bud, pistillode short. Female flowers pedicellate, tepals 4 , free or connate at base, lobes subequal, two large plus two opposite smaller, ciliolate along the margin, $1 \mathrm{~mm}$ long; ovary $1 \mathrm{~mm}$ long, oblique; stigmas deeply trilobed, usually filiform, central lobe longer than the other two lobes, papillae on one side, ovary with one erect ovule; staminodes absent. Achenes minute, 1.0-1.5 mm in diam., oblique, flattened, compressed, completely surrounded by a narrow membranous wing along the margin, obliquely stipitate, embraced by persistent hairy perianth; fruiting pedicels small, with stinging hairs. 
Phenology: Flowering occurs from early August and continues till early October; fruiting usually seen in October to late November. The collection site is relatively seasonal; having almost seven months dry period and five months cold winter and semi dry.

Etymology: The specific epithet of Laportea stolonifera is named after the unique character, 'stolonifera', the presence of 2 or 3 stolons.

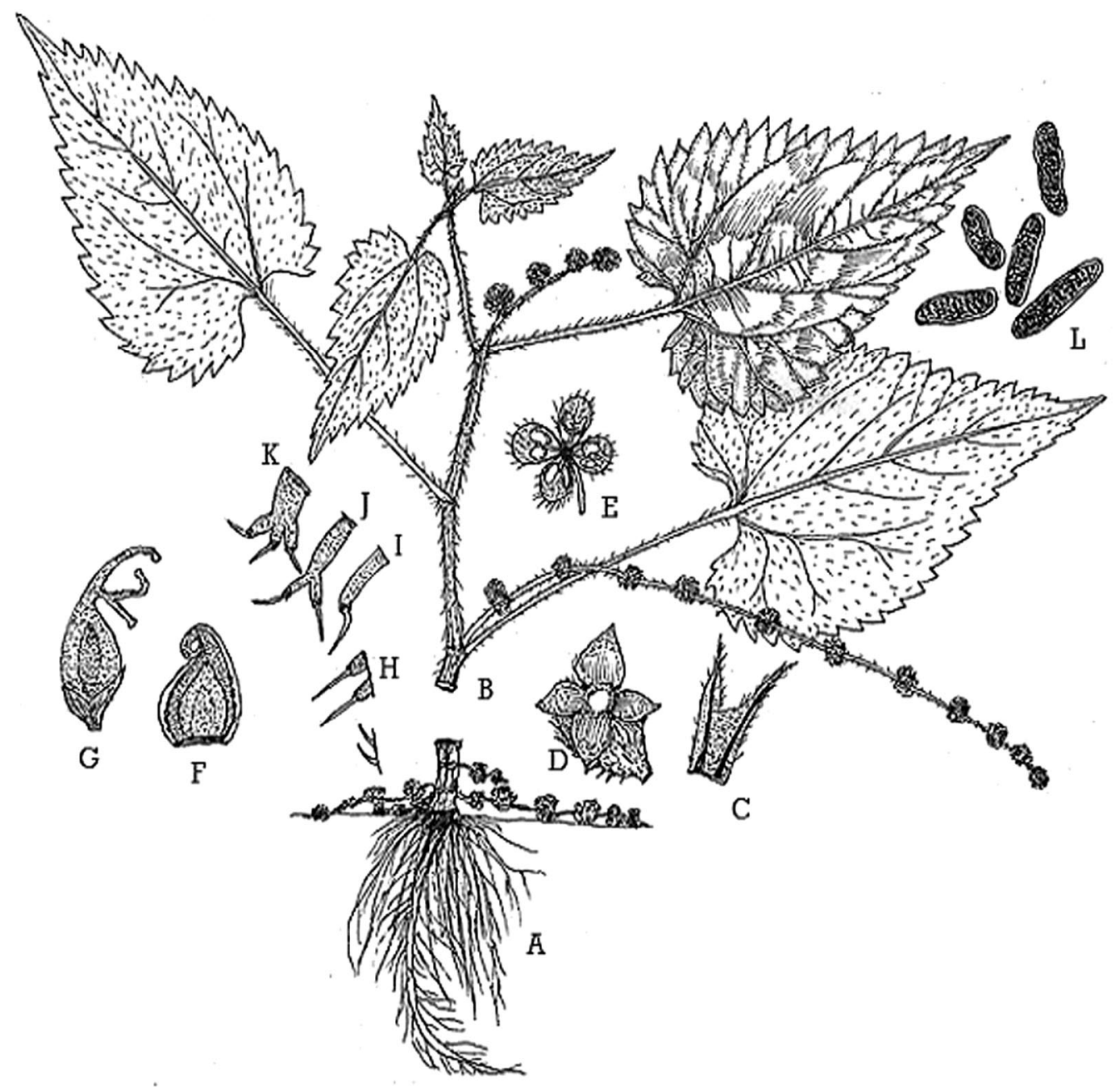

Fig. 1. Illustration of Laportea stolonifera B. L. Bhellum \& B. Singh, sp. nov.; (A) basal portion of stem bearing roots and stoloniferous inflorescence, (B) upper portion of stem bearing inflorescence, (C) stipule, (D) female flower, (E) male flower, (F) fruit, (G) pistil, (H-K) different kind of hairs, and (L) cystoliths. Illustration based on living material and voucher specimens deposited at RRLH.

Distribution and habitat ecology: Lower subtropical forest areas of Jasrota in Jammu province. The plant species grows gregariously as annual herbs along the stream-sides under moderately dense forest canopy cover. The sites where it occurs are located at an elevation of 250 
to $400 \mathrm{~m}$ above sea level (ASL). Plant prefers clayey to sandy types of edaphic habitat. Commonly associated species includes Oxalis corniculata L., Scutellaria prostrata Jacq. ex Benth., Mazus pumilus (Burm. f.) Steenis and Urtica dioica L.

Conservation status: Laportea stolonifera specimens were studied from three populations confined to the Jasrota forest. From these, 1196 matured individuals and 61 seedlings were recorded. In total 1257 individuals of plants were recorded in an area of less than $10 \mathrm{~km}^{2}$. The assessment of the IUCN status of L. stolonifera were done following 2001 IUCN Red List Categories and Criteria version 3.1, and for this particular species IUCN Guidelines for Application of IUCN Red List Criteria at Regional and National Levels Criteria version 4.0 (IUCN, 2010) were followed. Data reveals that L. stolonifera should be treated as Endangered (EN) $[\mathrm{A} 1(\mathrm{a}, \mathrm{b}, \mathrm{c}, \mathrm{d}) \cdot \mathrm{B} 2(\mathrm{a}, \mathrm{b}(\mathrm{i}, \mathrm{ii}, \mathrm{iv}, \mathrm{v}) \cdot \mathrm{C} 2 \mathrm{a}(\mathrm{i} . \mathrm{ii})]$.

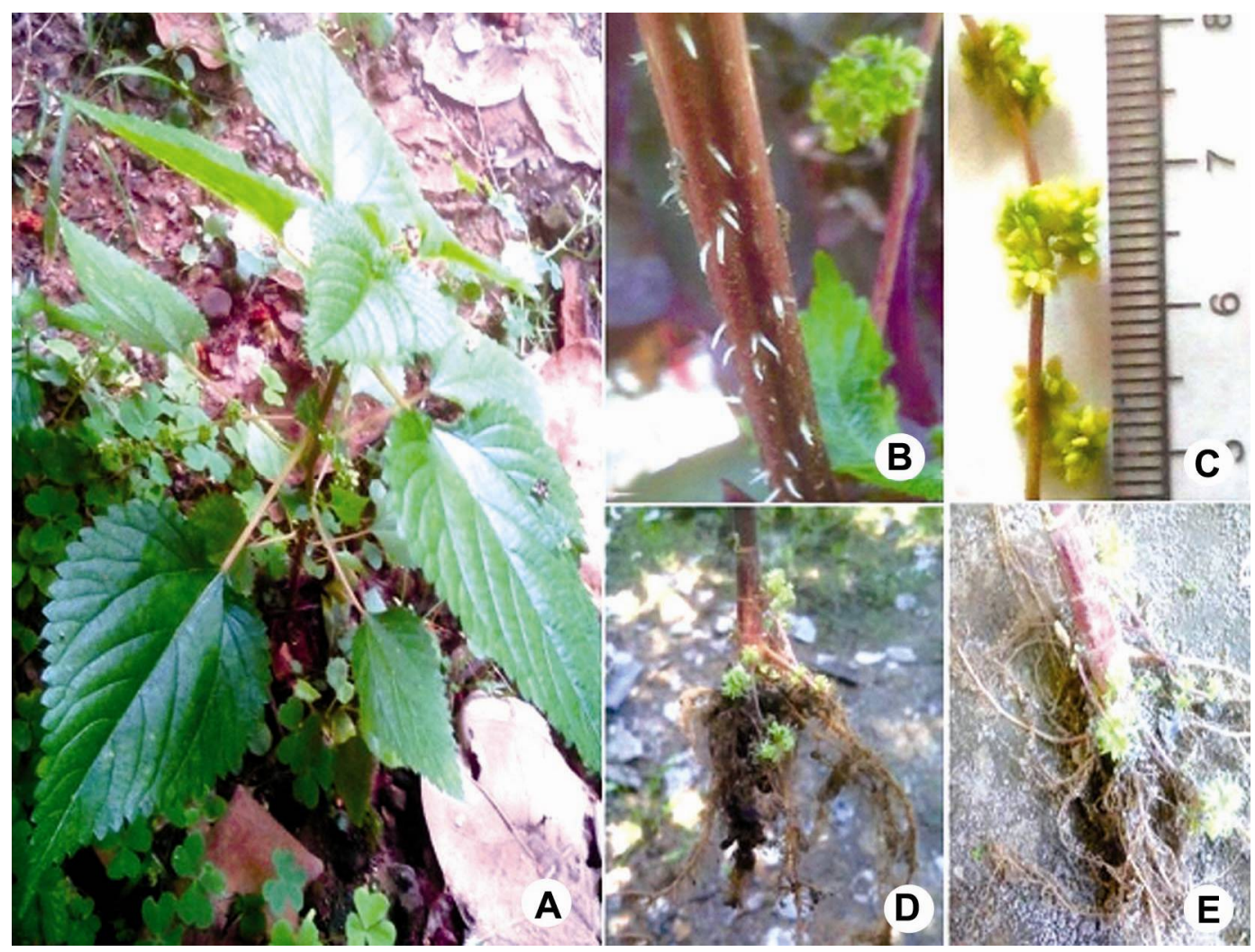

Fig. 2. Laportea stolonifera B.L. Bhellum \& B. Singh, sp. nov.; (A) Habit, (B) Portion of stem showing hairs, (C) Inflorescence, (D-E) Basal portion of stems bearing roots and stoloniferous inflorescence.

\section{Discussion}

After detailed studies, Laportea stolonifera is found to be very close to L. ovalifolia morphologically, and few characters were also matching with that of $L$. interrupta. The altitudinal distributions of the allied species were also geographically isolated from each other. L. stolonifera is confined to Jasrota forest belts of Jammu province only, which occupies the innermost Northwest Himalayan belts of India, whereas the related species L. ovalifolia and L. interrupta, 
were reported from Northeast India (Indo-Myanmar Hotspot region) in Eastern Himalaya and African endemic, respectively. The occurrences of these two species do not over-lap as they are geographically isolated by deserts, hills and mountains.

While examining the new species, Laportea stolonifera, from national and international herbaria, and comparing the description of the species, the authors developed a key for identification of of Laportea species from India.

\section{Key to the genus Laportea in India}

1. Often herbs with woody bulbils in leaf axils; pedicels of female flowers conspicuously laterally and symmetrically winged; achenes articulated on pedicel; stolons absent

L. bulbifera

- Herbs without bulbils in leaf axils; pedicels of female flowers slightly dorsiventrally and asymmetrically winged, or not winged; achenes not articulated on pedicel; stolons present

2. Inflorescence paniculate; stigma ligulated

- Inflorescence spicate; stigma 3-fid

3 Leaves broadly ovate to cordate, $1.0-8.4 \mathrm{~cm}$ long, $0.6-6.1 \mathrm{~cm}$ wide, upper surface packed with tiny sand-like cystoliths; inflorescence paniculate; 1-6 $\mathrm{cm}$ long, arise from base of stem directly from nodes; solons present, 2 or 3 in numbers

L. stolonifera

- Leaves ovate, 5-8 $\mathrm{cm}$ long, 4.0-5.5 $\mathrm{cm}$ wide, both surfaces packed with cystoliths; inflorescence paniculate, 8-28 cm long, arise from upper half of the stem; solons absent

L. interrupta

\section{Acknowledgements}

Authors are grateful to Prof. A. K. Koul, Centre for Biodiversity, Baba Gulam Shah Badshah University (Rajouri), and Prof. Rani Magotra Department of Botany, University of Jammu (Jammu) for encouragement. Thanks are due to Director, Dr. Ram. A. Vishwakarma, CSIR-Indian Institute of Integrative Medicine for providing Herbarium facilities and keeping the records of voucher samples. Authors would like to thanks the reviewers for suggestions. Thanks are also due to Mr. Pyrus Bhellum for technical assistance. This article represents CSIR-IIIM institutional communication number IIIM/1899/2016.

\section{References}

Anonymous 2015. 200 new animal and plant species discovered in the Himalayas. http://www.wired.co.uk.

Bennet, S.S.R. 1987. Name changes in flowering plants of India and adjacent regions. Triseas Publishers, Dehradun, India.

Chew, W.L. 1989. Urticaceae. In: Flora of Australia. vol. 3. Australia Government Publishing series, Canberra 190, pp. 68-93.

Fyson, P.F. 1974. The Flora of Nilgiri and Pulney Hilltops. Bishen Singh Mahendra Pal Sing, Dehra Dun, India. First ed. 1915.

IUCN. 2001. IUCN Red List Categories and Criteria. Version 3.1. http://www.iucnredlist.org/technicaldocuments/categories-and-criteria/2001-categories-criteria

IUCN 2010. Guidelines for using the IUCN Red List Categories and Criteria, Version 4.0. http://intranet.iucn.org/webfiles/doc/SSC/RedList/RedList Guidelines.pdf 
Mabberley, D.J. 2008 Mabberley's Plant-book: a portable dictionary of plants, their classification and uses. Third Edition. Cambridgen University Press.

Ramaswamy, S.V. and Razi, B.A. 1973. Flora of Bangalore District. Parasaranga, University of Mysore, India.

Sharma, B.M. 2010. Illustrations of Jammu Plants, a supplement to flora of Jammu and plants of neighbourhood with general key and annotation. Bishen Singh Mahendra Pal Singh, Dehra Dun, India.

Thiers, B. 2015. Index Herbariorum: A global directory of public Herbaria and associated staff. New York Botanical Garden's Virtual Herbarium. Available from: http://sweetgum.nybg.org/ih/ (accessed 07 March 2016)

TPL.2016. The Plant List, a working list of all known plant species. Version 1.1, released in September 2013. Online: http://www.theplantlist.org.

Wilmot-Dear, C.M. 2009 Urticaceae for the non-specialist: Identification in the Flora Malesiana region, Indochina and Thailand. Blumea 54(1-3): 233-241.

(Manuscript received on 26 May 2016; revised on 1 August 2016) 